\title{
Upaya Meningkatkan Minat dan Hasil Belajar IPA Melalui Penerapan Metode Eksperimen Pada Siswa Kelas VI Semester Ganjil SDN Inpres Cenggu Tahun Pelajaran 2016/2017
}

\author{
Umi Kaltum \\ SDN Inpres Cenggu \\ umi_kaltum70@gmail.com
}

\begin{abstract}
Pembelajaran IPA bertujuan untuk mrmahami pengetahuan tentang fakta-fakta, konsep IPA, tetapi untuk mengembangkan keterampilan ini sikap dan nilai-nilai yang diperlukan untuk mencapai pengetahuan itu.denga kata lain, harus ada ada peningkatan pada minat dan hasil belajar IPA bukan hanya sebagai produk. Penelitian ini bertujuan untuk mengetahui apakah penerapan Metode Eksperimen dapat meningkatkan minat dan hasil belajar IPA Siswa Kelas VI Semester Ganjil SDN Inpres Cenggu Tahun Pelajaran 2016/2017. Jenis ini adalah Penelitian Tindakan Kelas (PTK), Desain Penelitian Tindakan Kelas yang digunakan sesuai dengan model PTK Kemmis dan McTaggart. Setiap siklus meliputi perencanaan (plan), tindakan, pengamatan, evaluasi serta refleksi. Subyek dalam penelitian ini adalah siswa SDN Inpres Cenggu Tahun Pelajaran 2016/2017 sebanyak 25 orang. Instrumen yang digunakan dalam penelitian ini adalah soal tes dan lembar observasi. Berdasarkan analisis data yang telah dilakukan maka disimpulkan bahwa: (1) Penerapan Metode Eksperimen dapat meningkatkan minat belajar IPA Siswa Kelas VI Semester Ganjil SDN Inpres Cenggu Tahun Pelajaran 2016/2017. Peningkatan tersebut dibuktikan dengan persentase minat siswa yang selalu meningkat di setiap siklusnya. Persentase minat siswa pada siklus I sebesar 68\%, pada siklus II Sebesar $81 \%$ (2) Penerapan Metode Eksperimen dapat meningkatkan hasil belajar IPA Siswa Kelas VI Semester Ganjil SDN Inpres Cenggu Tahun Pelajaran 2016/2017. Hal ini dapat dibuktikan dari hasil tes belajar siswa dari siklus ke siklus II yang mengalami peningkatan. Pada siklus I persentase ketuntasan 68\%. Pada siklus II mengalami peningkatan dengan persentase ketuntasan $88 \%$.
\end{abstract}

Keywords:Minat belajar, Hasil belajar, metode Eksperimen

\section{PENDAHULUAN}

Minat dan hasil belajar peserta didik

Kelas VI rendah. Hal ini terbukti padasaatpembelajaran berlangsung siswa kurang memperhatikan penjelasan guru, siswa kurang tertib, siswa kurang berani menjawab pertanyaan guru, dan siswa tidak berani bertanya saat mengalami kesulitan dalam pembelajaran, bahkan diantara mereka suka bermain sendiri. Dari hasil ulangan harian yang dilakukan, hanya 15 dari 25 pesertadidik kelas VI yang memperoleh nilai kurang dari 75 (42\%). Kondisi seperti ini tentunya cukup memprihatikan sehingga perlu segera dicari solusinyaagar minat dan hasil belajar IPA dapat meningkat.

Rendahnya minat dan hasil belajar IPA peserta didik kelas VI disebabkab karena dalam pembelajaran aktifitas guru lebih menonjol bila dibandingkan dengan aktifitas murid, guru kuang variatif dalam mengelola pembelajaran. Pembelajaran di kelas masih banyak dilakukan dengan menempatkan siswa sebagai pendengar sehingga mereka cenderung pasif dan kurang bergairah dalam mengikuti pembelajaran IPA dikelasnya.

Berangkat masalah diatas perlu ditemukan cara terbaik dalam pembelajaran guna menyampaikan konsep materi kepada peserta didik yang diharapkan adalah meningkatkan minat dan hasil belajar IPA dengan kriteria Ketuntasan Minimum (KKM) yang telah ditetapkan yaitu perolehan nilai $\geq$ 68 .

Ketidakberhasilan peserta didik kelas VI dalam pembelajaran IPA dikarenakan guru belum menggunakan metode pembelajaran yang tepat dalam kegiatan belajar mengajar Proses pembelajaran kurang kondusif karena banyak menggunakan metode cerah. Peneliti 
harus melakukan tindakan untuk memperbaiki ketidak berhasilan tersebut dengan membangkitkan minat belajar peserta didik pada pross pembelajaran IPA menggunakan metode eksperimen. hal ini sangat penting karena diharapkan dengan menggunakan metode eksperimen minat pelajaran IPA materi perubahan benda dapat meningkat. mengingat IPA adalah salah satu matapelajaran yang di-USBN-kan.

Tidak sedikit peserta didik memandang matapelajaran IPA sebagai pelajaran yang menyeramkan, menakutkan, sulit bahkan rumit untuk dipahami. Banyak peserta didik yang menyukai mata pelajaran tersebut, kalaupun mengikuti mereka tidak berminat dalam pembelajaran sehingga penguasaan materi tidak maksimal dan berakibat hasil belajar IPA rendah. Kenyataan ini merupakan suatu masalah yang harus diperhatikan dalam mewujudkan tujuan pembelajaran IPA. oleh karena itu, menciptakan proses pembelajaran IPA yang menarik dan di senangi oleh anak-anak harus menjadi perioritas utama. sementara itu, dalam pembelajaran guru masih menggunakan cara-cara lama tampa menggunakan metode pembelajaran yang bervariasi tanpa memperdulikan apakah minat dan hasil belajar IPA. Penulis mencoba memperbaiki pembelajaran agar menjadi menarik, bervariasi, menyenangkan, dan bermakna bagi peserta didik dengan melakukan tindakan melalui penggunaan metode eksperimen.

Berdasarkan latar belakang masalah diatas penulis mengangkat judul penelitian: upaya meningkatkan minat dan hasil belajar IPA melalui penerapan metode eksperimen pada siswa kelas VI semester ganjil SDN Inpres Cenggu Tahun pelajaran 2016/2017.

\section{METODE}

\section{Jenis Penelitian}

Penelitian ini adalah Penelitian Tindakan Kelas (PTK). Penelitian tindakan kelas (PTK) harus tertuju atau mengenai halhal yang terjadi didalam kelas (Aqib, 2007). Setiap siklus meliputi perencanaan, tindakan, pengamatan, evaluasi serta refleksi (Azmin,
2019)

Model dan penjelasan masing- masing tahap menurut Arikunto (2010) dan akan dilakukan dalam penelitian ini adalah sebagai berikut:

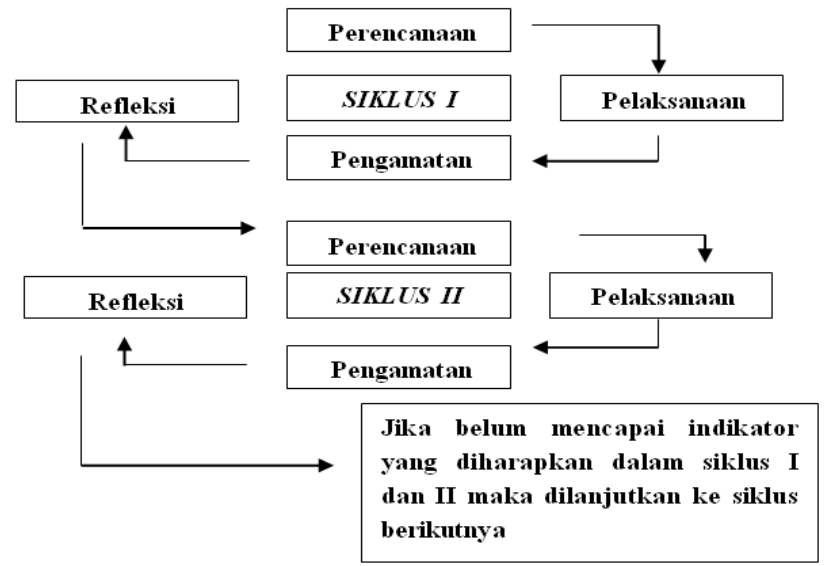

Gambar 1. Siklus PTK Model Arikunto

\section{Waktu dan Tempat Penelitian}

Penelitian ini dilaksanakan di SDN Inpres Cenggu, pada Semester Ganjil Tahun Pelajaran 2016/2017.

\section{Subyek Penelitian}

Subyek dalam penelitian ini adalah siswa SDN Inpres Cenggu Tahun Pelajaran 2016/2017 sebanyak 25 orang.

\section{Prosedur Penelitian}

Kegiatan penelitian tindakan kelas ini terdiri dari 2 siklus dengan alasan keterbatasan waktu dan kompetensi dasar yang diajarkan dalam penelitian. Penelitian ini diawali kegiatan observasi sebagai penjajakan untuk memperoleh informasi dan gambaran terhadap permasalahan yang sedang dihadapi, dan tindakan yang dilakukan guru dan dilanjutkan dengan membahas hasil observasi serta merencanakan dan penetapan tindakan. Prosedur penelitian tindakan kelas ini setiap siklus meliputi kegiatan:

\section{Perencanaan}

Rencana tindakan yang akan dilakukan untuk memperbaiki, meningkatkan atau perubahan perilaku dan sikap sebagai solusi. Pada tahap perencanaan dilakukan dengan menyusun perencanaan tindakan berdasarkan identifikasi masalah pada prosentasi awal sebelum penelitian dilakukan.

Secara terinci prosedur penelitian 
tindakan ini dijabarkan sebagai berikut:

Siklus I dilaksanakan 1 kali pertemuan dengan tahapan sebagai berikut:

1) Menyusun (RPP) dengan menggunakan metode eksperimen.

2) Menetapkan alat dan bahan untuk melakukan eksprimen pada mata pelajaran IPA tentang materi perpindahan dan perubahan energi listrik.

3) Menyiapkan (LKS) berbentuk kegiatan unjuk kerja siswa.

4) Menyiapkan instrument tes tulis berupa lembar soal tes uraian.

5) Menyiapkan instrument non tes berupa lembar lembar observasi guru dan siswa dalam kegiatan pembelajaran, serta angket minat belajar siswa.

2. Pelaksanaan Tindakan

Pelaksanaan tindakan merupakan proses kegiatan pembelajaran kelas sebagai realisasi dari teori dan strategi belajar mengajar yang telah disiapkan serta mengacu pada kurikulum yang berlaku, dan hasil yang diperoleh diharapkan dapat meningkatkan kerjasama penelitian dengan subjek penelitian sehingga dapat memberikan refleksi dan evaluasi terhadap apa yang terjadi di kelas. Adapun Tindakan yang akan dilakukan adalah:

1) Melaksanakan pembelajaran sesuai dengan perencanaan pembelajaran.

2) Melakukan tes siklus I untuk mendapatkan data mengenai hasil belajar siswa pada mata pelajaran IPA.

3) Membagikan angket minat belajar kepada siswa untuk diisi.

3. Observasi

Observasi yaitu mengamati atas hasil atau dampak dari tindakan yang di laksanakan atau dikenakan terhadap siswa. Tahap obsevasi merupakan kegiatan pengamatan langsung terhadap pelaksaan tindakan yang dilakukan dalam PTK. Guru melakukan pengamatan terhadap :

1) Mengamati minat kelompok para siswa dan keberhasilan para siswa dalam melaksanakan tugas.

2) Mengamati penggunaan alat peraga dalam proses pembelajaran.

3) Mengamati jalannya proses pembelajaran
4) Mengamati jalannya proses pembelajaran.

5) Mengamati aktifitas para siswa dalam menyelesaikan LKS

6) Mengamati siswa dalam membuat kesimpulan

4. Refleksi

Peneliti dibantu oleh observer melakukan refleksi terhadap pelaksanan siklus pertama untuk perbaikan disiklus selanjutnya. Serta mengetahui kelebihan dan kekurangan ketika pelaksanaan siklus I.

Siklus II dilaksanakan 1 kali pertemuan dengan tahapan sebagai berikut:

1. Perencanaan.

Peneliti membuat rencana pembelajaran berdasarkan refleksi berdasarkan siklus II dan menetapkan alat dan bahan untuk melakukan eksperimen.

Ada beberapa rencana tindakan yang guru siapkan untuk dilaksanakan selama penelitian. Rencana tindakan itu adalah sebagai berikut :

1) Memperbaiki Rencana Pelaksanaan Pembelajaran (RPP) yang sesuai dengan metode pembelajaran eksperimen.

2) Mempersiapkan alat, sarana dan media pembelajaran materi perpindahan dan perubahan energi listrik yang memadai.

3) Membuat lembar kerja siswa.

4) Merancang pembentukan kelompok sesuai dengan keberagaman kemampuan dan menata tempat duduk agar pembelajaran lebih efektif.

5) Menyusun tes untuk mengetahui hasil belajar para siswa

6) Menyiapkan lembar observasi dan angket minat belajar siswa dalam pelaksanaan kegiatan pembelajaran.

2. Pelaksanaan Tindakan

Peneliti melaksanakan pembelajaran menggunakan metode eksperimen berdasarkan rencana pembelajaran hasil refleksi pada siklus pertama. Kegiatan menggunakan metode eksperimen pada pembelajaran hasil refleksi pada siklus I adalah sebagai berikut:

1) Guru memberikan informasi awal tentang jalannya pembelajaran dan tugas yang harus dilaksanakan pada siswa secara singkat dan jelas. 
2) Guru menyajikan materi tentang perpindahan dan perubahan energi listrik.

3) Pembentukan kelompok belajar dengan kemampuan yang beragam dan menata tempat duduk agar pembelajaran lebih efektif.

4) Guru memberikan alat peraga, kemudian siswa melakukan kegiatan eksperimen sesuai dengan materi yang disajikan guru. Mengerjakan LKS secara berkelompok.

5) Siswa membuat kesimpulan dari konsepkonsep materi eksperimen.

6) Membahas hasil pekerjaan eksperimen dari siswa

7) Pemberian evaluasi dari hasil siklus dan angket minat belajar.

3. Observasi

Peneliti dibantu 2 observasi yang bertugas mengamati minat siswa dalam pelaksanaan pembelajaran menggunakan metode eksperimen. Guru melakukan pengamatan terhadap:

1) Mengamati minat kelompok para siswa dan keberhasilan para siswa.

2) Mengamati penggunaan alat peraga dalam proses pembelajaran.

3) Mengamati siswa yang aktif berinteraksi.

4) Mengamati jalannya proses pembelajaran.

5) Mengamati aktifitas para siswa dalam menyelesaikan LKS.

6) Mengamati siswa dalam membuat kesimpulan.

4. Refleksi

Peneliti melakukan refleksi bersama observasi terhadap pelaksanaan siklus kedua dan menganalisis kekurangan dan kelebihannya.

\section{Instrumen Penelitian}

Instrumen Instrument yang digunakan dalam penelitian ini terdiri dari: Angket Minat Belajar, Soal Tes hasil belajar, dan Lembar Observasi

\section{Teknik Analisis Data}

1. Minat Belajar

Data minat belajar siswa dianalisis menggunakan analisis deskriptif kuantitatif. Analisisi deskriptif kuantitatif dilakukan menggunakan skala likert dengan gradasi sangat baik, baik, tidak baik dan sangat tidak baik. Pertanyaan pada angket berupa pertanyaan positif negatif. Untuk skor pertanyaan positif diberikan 5 untuk poin sangat setuju (SS) 4 untuk setuju (S), 3 untuk ragu-ragu (R), 2 untuk tidak setuju (TS), dan 1 untuk sangat tidak setuju (STS). Sedangkan untuk pertanyaan negatif diberikan Untuk skor 1 untuk poin sangat setuju (SS) 2 untuk setuju (S), 3 untuk ragu-ragu (R), 4 untuk tidak setuju (TS), dan 5 untuk sangat tidak setuju (STS). Siswa diminta untuk memilih salah satu jawaban yang sesuai dengan keadaan masing-masing. Angket ini digunakan untuk mengetahui minat belajar siswa. Hasil analisi minat dilakukan secara deskriptif disajikan dalam persentase. Kategori persentase mengacu pada tabel berikut:

Tabel 1. Persentase Kategori Minat Belajar

\begin{tabular}{|c|c|}
\hline Persentase & Kriteria \\
\hline $86 \%-100 \%$ & Sangat baik \\
\hline $76 \%-85 \%$ & Baik \\
\hline $60 \%-75 \%$ & Cukup \\
\hline $55 \%-59 \%$ & Kurang \\
\hline $54 \%$ & Kurang sekali \\
\hline
\end{tabular}

2. Hasil Belajar

Analisis data hasil belajar dilakukan secara deskriptif dan disajikan dalam persentase, Indikator keberhasilan Hasil belajar siswa dikatakan meningkat apabila tercapainya ketuntasan belajar secara klasikal yaitu $\geq 75 \%$ dan siswa memperoleh nilai ketuntasan individual $\geq 75$. minat belajar siswa dikatakan meningkat apabila terjadinya peningkatan skor setiap siklusnya.

\section{HASIL DAN PEMBAHASAN Hasil Penelitian \\ Kondisi Awal Siswa}

Pembelajaran yang terjadi di SDN Inpres Cenggu adalah sudah cukup baik hanya mungkin keadaan fasilitas dan guru yang ada beberapa kurang berkompetensi dalam pemberian pembelajaran. Minimnya media dan sumber belajar dalam melaksankan kegiatan belajar mengajar setiap hari, sehingga kadang murid kurang bisa dalam 
menangkap apa yang diberikan oleh guru. Apalagi bagi anak SD harus diajarkan dengan metodr-metode maupun model yang bervariasi agar mereka semakin termotivasi dalam belajar.

Berdasarkan pengamatan dilapangan, proses pembelajaran kelas VI di SDN Inpres Cenggu masih berpusat pada guru sehingga belum mampu membangkitkan budaya belajar pada diri siswa. Tenaga pendidik masih menggunakan model pembelajaran konvensional secara monoton dalam kegiatan pembelajaran di kelas, sehingga suasana ) yang diharapkan mampu mengatasi masalah pembelajaran yang ada. Rencana tindakan di atas berpedoman pada rencana pembelajaran dengan langkah-langkah perbaikan pembelalajaran yang dilaksanakan dalam 2 siklus.

\section{Hasil Siklus I}

Perbaikan pembelajaran siklus I merupakan usaha perbaikan pembelajaran dari hasil yang dicapai pada pembelajaran yang dilaksanakan sebelumnya. Pelaksanaan rencanaan tindakan, perbaikan pembelajaran dari hasil yang dicapai pada pembelajaran yang dilaksanakan sebelumnya. Perbaikan pembelajaran pada siklus I ini dilakukan tindakan dengan menggunakan metode pembelajaran Eksperimen. Pada tindakan siklus I ini, guru sebagai peneliti dan pelaksana pembelajaran, terlebih dahulu menyusun perencanaan tindakan, pelaksanaan tindakan, hasil pengamatan, dan refleksi

\section{Perencanaan}

\section{a. Pendahuluan}

Pada tahap awal kegiatan guru mengidentifikasi masalah, menganalisis dan merumuskan masalah, mendiskusikan penggunaan metode dan media dalam pembelajaran. Guru membuat Rencana Pelaksanaan Pembelajaran tentang materi yang akan diajarkan, yaitu materi pelajaran IPA perpindahan dan perubahan energi listrik dengan metode pembelajaran eksperimen. Guru juga menyiapkan instrumen yang digunakan.

b. Inti

Pada langkah ini guru mencantumkan materi pelajaran tentang perpindahan dan perubahan energi listrik, sebagai pedoman dalam menyampaikan materi pelajaran. Selanjutnya melanjutkan skenario pembelajaran yang tertuang pada langkahlangkah pembelajaran, yang terdiri dari kegiatan Awal, kegiatan inti dan kegiatan akhir.

c. Penutup

Pada akhir kegiatan ditampilkan tes evaluasi berupa uji kompetensi tentang materi pembelajaran, berupa soal IPA materi perpindahan dan perubahan energi listrik.

2. Pelaksanaan Tindakan

Pelaksanaan tindakan dilakukan sesuai dengan rencana yang telah direncanakan pada tindakan perencanaan di atas.

a. Pendahuluan

Pada tahap awal kegiatan, guru mengecek kesiapan siswa dilanjutkan dengan berdoa dan mengabsen kehadiran siswa. Menyampaikan tujuan pembelajaran dan kompetensi yang diharapkan. Guru memberi apersepsi dan motivasi dengan bercerita tentang contoh rangkaian seri agar siswa menjadi antusias untuk mempelajari tentang materi rangkaian seri. b. Inti

Pada kegiatan inti guru memulai sedikit memberi materi melalui diskusi tentang apa itu rangkaian seri, sambil diberikan contoh gambar rangkaian seri.

Guru lalu melakukan pembentukan kelompok belajar dengan kemampuan yang beragam dan menata tempat duduk agar pembelajaran lebih efektif. Guru kemudian memberikan alat peraga, kemudian siswa melakukan kegiatan eksperimen sesuai dengan materi yang disajikan guru. Siswa mengerjakan tugas secara kelompok. Guru berkeliling melihat dan mengecek kerja dari setiap kelompok. Setelah dua perwakilan kelompok maju untuk menyampaikan hasil tugas mereka. Guru memberikan kesempatan kepada siswa untuk bertanya tentang materi yang belum dimengerti.

c. Penutup

Pada kegiatan penutup guru dan siswa 
melakukan langkah-langkah sebagai berikut: 1). siswa dibimbing guru menyimpulkan hasil belajar, 2). guru memberikan tes dan dan membagikan angket minat belajar, 3). guru memberikan pesan belajar agar siwa mempelajari kembali materi yang didapat. Guru memberitahukan materi pada pertemuan berikutnya.

3. Pengamatan

Hasil pengamatan siklus I dicatat dalam lemabar observasi yang telah dipersiapkan.

a. Hasil Pengamatan pada Proses pembelajaran.

Proses pembelajaran yang terjadi pada siklus I menunjukkan adanya suatu perubahan tingkah laku peserta didik saat mengikuti kegiatan pembelajaran. Peserta didik siswa kurang aktif dalam bekerja kelompok serta siswa kurang berani mengemukakan pendapat dalampenggunaan metode pembelajaran "Eksperimen". Peserta didik masih banyak yang belum berminat dalam mengkuti pembelajaran.

b. Hasil Pengamatan pada hasil belajar

Hasil pembelajaran pada siklus I menunjukan bahwa nilai tertinggi yang dicapai siswa adalah 80 dan nilai terendah adalah 60 dengan rata-rata kelas $68 \%$.

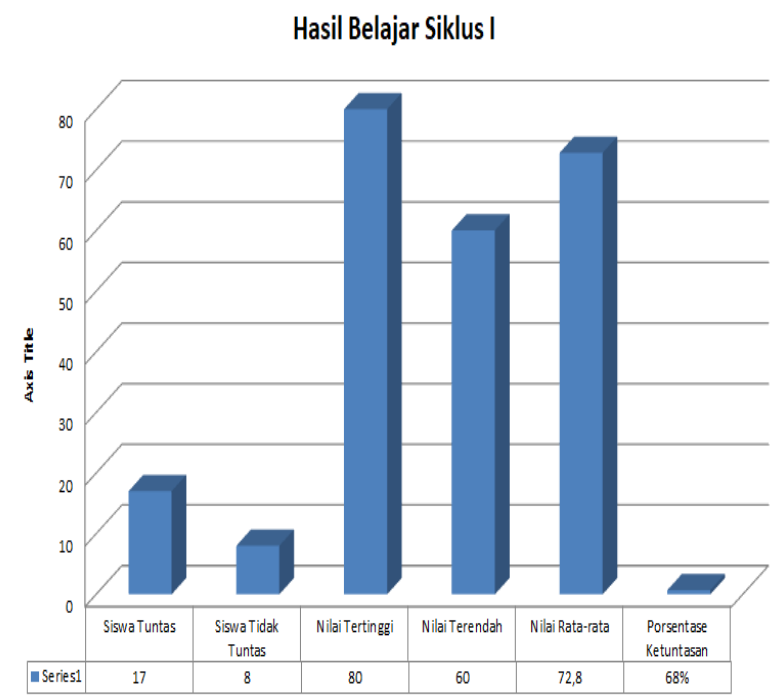

Gambar 1. Hasil Belajar siklus I

Dilihat dari ketuntasan belajar siswa, maka dari 25 siswa yang sudah berhasil mencapai kriteria ketuntasan minimal sebanyak 17 siswa (68\%) dan siswa yang belum tuntas sebanyak 8 siswa (32\%).

Sementara hasil analisis angket didapatkan sebagai berikut:

Tabel 2. Rekapitulasi minat siswa siklus I

\begin{tabular}{|l|c|l|}
\hline Pernyataan (1-25) & $\begin{array}{c}\text { Rata-rata } \\
\text { Skor }\end{array}$ & Kategori \\
\hline Jumlah & 1729,6 & \multirow{2}{*}{ Cukup Baik } \\
\cline { 1 - 2 } Rata-rata & 86,48 & \\
\hline Kriteria & $69 \%$ & \\
\hline
\end{tabular}

Berdasarkan tabel 2 diketahui minat siswa pada siklus I rata-rata $69 \%$ dengan cukup baik. Siswa masih belum begitu tertarik saat proses pembelajaran menggunakan metode eksperimen. Siswa sudah mulai menganggap pembelajaran lebih mudah menggunakan metode eksperimen.

4. Refleksi

Berdasarkan hasil pengamatan pada siklus I hasil belajar dan minat siswa masih kurang dalam proses pembelajaran. Adapun yang menjadi kendalanya sebagai berikut:

a. Peserta didik sudah mulai berminat makin mengikuti pembelajaran, siswa mulai aktif dalam kelompok besar memperhatikan pelajaran, melalui eksperimen sumber belajar siswa sudah mulai bervariasi

b. Hasil evaluasi pada siklus I nilai hasil belajar baru $68 \%$ siswa yang tuntas, dan minat siswa baru $69 \%$ pada kategori cukup baik.

Hasil tersebut menunjukkan bahwa pada siklus pertama secara klasikal siswa belum tuntas lebih kecil dari persentase ketuntasan yang dikehendaki yaitu sebesar $75 \%$ dan tingkat minat belajar sebesar $69 \%$ pada kategori cukup baik, maka dilakukan ke siklus ke II.

\section{Hasil Siklus II}

Melihat hasil siklus I yang kurang maksimal, maka guna memaksimalkan hasil yang diingin dicapai maka dilakukan siklus lanjutan. Sebelum melaksanakan perbaikan pembelajaran siklus 2 guru sebagai peeliti dan pelaksana pembelajaran mengadakan diskusi dengan observer dan teman sejawat untuk 
menentukan langkah-langkah perbaikan pembelajaran tahap berikutnya. Semua kekurangan yang terjadi pada siklus I akan diadakan perbaikan oleh guru sebagai peneliti dan pelaksana pembelajaran pada siklus II. Pada siklus II ini kegiatan dilaksanakan seperti pada siklus I yaitu penyajian materi dengan menggunakan metode pembelajaran "Eksperimen" untuk meningkatkan minat dan hasil belajar peserta didik secara kelompok besar. Adapun tahapan dalam siklus II yaitu:

\section{Perencanaan}

Perencanaan tindakan pada siklus II ini dilakukan tidak jauh beda dengan siklus I yaitu:

\section{a. Pendahuluan}

Pada tahap awal kegiatan guru mengidentifikasi masalah, menganalisis dan merumuskan masalah, mendiskusikan penggunaan metode dan media dalam pembelajaran. Guru membuat Rencana Pelaksanaan Pembelajaran (RPP) yang sesuai dengan meode pembelajaran eksperimen. Guru juga menyiapkan lembar kerja siswa siklus II Menyiapkan soal evaluasi yang digunakan untuk mengevaluasi hasil belajarsiswa Siklus II.

b. Inti

Pada langkah ini guru mencantumkan materi pelajaran. Selanjutnya melanjutkan skenario pembelajaran yang tertuang pada langkah-langkah pembelajaran, yang terdiri dari kegiatan Awal, kegiatan inti dan kegiatan akhir.

c. Penutup

Pada akhir kegiatan ditampilkan tes evaluasi hasil belajar tentang materi pembelajaran, dan menyebarkan angket minat belajar.

\section{Pelaksanaan}

Pelaksanaan tindakan yang dilakukan pada siklus II ini, dilakukan dengan melihat hasil pada siklus I, dengan melihat kekurangan yang ada, maka pada siklus II ini dilakukan langkah-langkah perbaikan. Tindakan yang dilakukan pada siklus II ini meliputi: Tindakan siklus II dilaksanakan dalam 1 kali pertemuan dengan alokasi waktu $2 \times 45$ menit dengan tahapan: Setelah guru memasuki ruang maka guru/peneliti menyampaikan tujuan pembelajaran, setelah itu guru mulai membagi siswa dalam kelompok-kelompok yang heterogen yang terdiri atas 3-5 siswa.

\section{Pengamatan}

Hasil pengamatan siklus II dicatat dalam lembar observasi yang telah dipersiapkan. Pengamatan siklus I diperoleh hasil sebagai berikut: bahwa $88 \%$ tuntas secara klasikal dalam pembelajaran dengan menggunakan metode eksperimen.

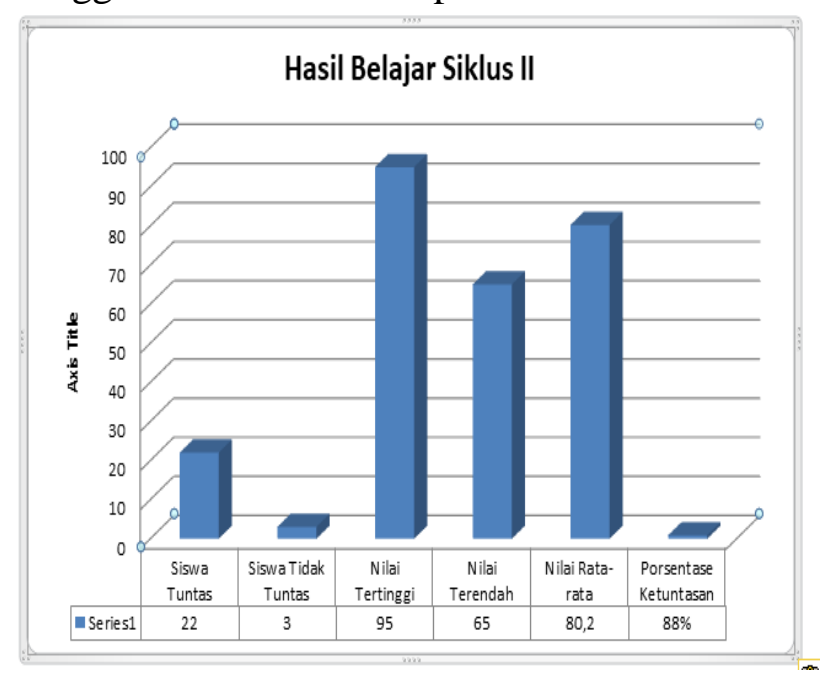

Gambar 2. Hasil Belajar Siklus II

Berdasarkan hasil observasi Peningkatan hasil dan aktivitas belajar merupakan tolak ukur untuk mengetahui tingkat keberhasilan siswa dalam proses belajar mengajar. Proses belajar mengajar dikatakan baik, bila proses tersebut dapat membangkitkan kegiatan belajar yang efektif.

Sementara hasil analisis angket didapatkan sebagai berikut:

Tabel 3. Rekapitulasi minat siswa siklus II

\begin{tabular}{|l|c|c|}
\hline Pernyataan (1-25) & $\begin{array}{c}\text { Rata-rata } \\
\text { Skor }\end{array}$ & Kategori \\
\hline Jumlah & 2032,8 & \multirow{2}{*}{ Baik } \\
\cline { 1 - 2 } Rata-rata & 101,64 & \multirow{2}{*}{ Bat } \\
\hline Kriteria & $81 \%$ & \\
\hline
\end{tabular}

Berdasarkan tabel 3 diketahui minat siswa pada siklus II memperoleh rata-rata $81 \%$ dengan kriteria baik. Siswa lebih tertarik saat proses pembelajaran menggunakan metode eksperimen. Siswa menganggap pembelajaran lebih mudah menggunakan 
metode eksperimen. Siswa merasa senang karena melalui metode tersebut merek dapat memahami secara nyata dengan melakukan eksperimen secara langsung. Pembelajaran secara berkelompok juga membuat siswa merasa senang. Peningkatan minat siswa diperoleh setelah melakukan berbagai macam upaya oleh peneliti dan guru kolaborator dengan membandingkan hasil pada siklus I

4. Refleksi

Pelaksanaan siklus II dengan materi yang disampaikan pada siklus II. Peneliti bersama guru kelas sebagai kolaborator mendiskusikan hasil pengamatan yang dilakukan dalam proses pembelajaran yang sudah berlangsung. Hasil diskusi yaitu menilai bahwa pembelajaran pada siklus II dapat menigkatkan minat siswa. Peningkatan tersebut ditandai dengan peningkatan pada hasil belajar yang diperoleh siswa melalui angket minat siswa, serta hasil belajar siswa pada proses pembelajaran yang cenderung lebih aktif dibandingkan dengan siklus I. Minat belajar siswa meningkat menjadi $81 \%$ pada kategori baik, sementara hasil belajar juga mengalami peningkatan menjadi $88 \%$ dan sudah melewati ketuntasan klasikal dari $75 \%$ yang telah ditetapkan.

\section{Pembahasan}

Berdasarkan proses pembelajaran dengan menggunakan metode eksperimen pada siklus I dan siklus II, maka diperoleh hasil peningkatan minat belajar siswa dan hasil belajara siswa. Minat belajar siswa meningkat menjadi $81 \%$ pada kategori baik, sementara hasil belajar juga mengalami peningkatan menjadi $88 \%$ dan sudah melewati ketuntasan klasikal dari $75 \%$ yang telah ditetapkan.

Guru dan siswa mampu bekerjasama dalam kelompok dan melakukan pembagian tugas pada masing-masing siswa dalam kelompok, sehingga setiap siswa memiliki peran, tugas dan tanggungjawab masingmasing. Peningkatan ini sejalan dengan apa yang dikatakan Roestiyah (2008), bahwa metode Eksperimen adalah salah satu cara mengajar, dimana siswa melakukan suatu percobaan tentang suatu hal, mengamati prosesnya serta menuliskan hasil percobaannya, kemudian hasil pengamatan itu disampaikan ke kelas dan dievaluasi oleh guru. Menurut Mulyani Sumantri (2001) Metode eksperimen atau percobaan diartikan sebagai cara belajar mengajar yang melibatkan siswa dengan mengalami dan membuktikan sendiri proses dan hasil percobaan itu. Jadi, dengan adanya pembelajaran IPA di Sekolah Dasar siswa dapat mempelajari tentang diri sendiri, alam semesta, serta kehidupan yang terjadi sehari-hari di masyarakat. Dan juga pembelajaran IPA menekankan pada pengalaman langsung dan kegiatan praktek yang akan mengembangkan kompetensi siswa tentang alam sekitar secara ilmiah.

\section{KESIMPULAN}

Berdasarkan hasil pembahasan diatas dapat disimpulkan bahwa:

1. Penerapan Metode Eksperimen dapat meningkatkan minat belajar IPA Siswa Kelas VI Semester Ganjil SDN Inpres Cenggu Tahun Pelajaran 2016/2017. Peningkatan tersebut dibuktikan dengan persentase minat siswa yang selalu meningkat di setiap siklusnya. Persentase minat siswa pada siklus I sebesar $68 \%$, pada siklus II Sebesar $81 \%$

2. Penerapan Metode Eksperimen dapat meningkatkan hasil belajar IPA Siswa Kelas VI Semester Ganjil SDN Inpres Cenggu Tahun Pelajaran 2016/2017. Hal ini dapat dibuktikan dari hasil tes belajar siswa dari siklus ke siklus II yang mengalami peningkatan. Pada siklus I persentase ketuntasan 68\%. Pada siklus II mengalami peningkatan dengan persentase ketuntasan $88 \%$.

\section{DAFTAR PUSTAKA}

Amin, Mohammad. 1987. Mengajar IPA dengan menggunakan metode discovery inquiry. Jakarta: Depdikbud

Aqib, 2007. Melaksanakan Penelitian Tindakan Kelas (PTK) Itu Mudah. Jakarta: Bumi Aksara.

Arikunto. S. 2010. Prosedur Penilitian Suatu 
Pendekatan Praktek. Jakarta:Renika

Cipta.

Azmin, N., \& Nasir, M. (2019).

PENERAPAN MODEL

PEMBELAJARAN 5E UNTUK

MENINGKATKAN

KETERAMPILAN PROSES SAINS

DAN SIKAP ILMIAH SISWA

KELAS VIII SMP NEGRI 6 KOTA

BIMA. ORYZA Jurnal Pendidikan

Biologi, 8(2), 40-46.

Mulyani Sumantri \& Johar Permana (2001), Strategi Belajar Mengajar, Bandung:

CV. Maulana

Roestiyah. 2008. Model dan Metode

Pembelajaran. Jakarta: Bumi Aksara

Samatoa, Usman. (2006). Bagaimana Membelajarkan IPA di Sekolah Dasar.

Jakarta. Departemen Pendidikan dan

Kebudayaan Direktorat Jendral Pendidikan Tinggi Sekolah Dasar.

Sofyan, Nurbaeti. 2004. Skripsi : Hubungan antara Minat dan Perhatian dengan Prestasi Belajar Siswa Mata Pelajaran IPA pada SDN Labuang Baji I Makassar. Makassar: Universitas Veteran Republik Indonesia.

Syah, Muhibbin. 2001. Psikologi Pendidikan dengan Pendekatan Baru.

Bandung:Remaja Rosdakarya. 